\section{Kữ Kamonu Eğitim Dergisi Kastamonu Education Journal}

Mart 2019 Cilt:27 Sayı:2

kefdergi.kastamonu.edu.tr
Başvuru Tarihi/Received: 26.03.2018

Kabul Tarihi/Accepted: 09.08.2018 DOI: 10.24106/kefdergi.2887

\title{
Problem Çözmede Başarılı Öğrencilerin Problem Çözmeye Yönelik Yansıtıcı Düşünme Becerilerinin İncelenmesi'
}

\section{The Examination of Reflective Thinking Skill Toward Problem Solving of Students With Successful at Solving Problem ${ }^{12}$}

\section{Öz}

\author{
Alaattin PUSMAZ ${ }^{3}$, Sevilay TAVŞAN ${ }^{4}$
}

Bu araştırmanın amacı, matematik problemlerini çözmede başarılı öğrencilerin problem çözmeye yönelik yansıtıcı düşünme becerilerinin incelenmesidir. Araştırmada, nitel araştırma modellerinden biri olan özel durum çalışması kullanılmıştır. Araştırmanın çalışma grubunu matematik problemlerini çözmede başarılı üç öğrenci oluşturmuştur. Veri toplama aracı olarak bireysel problem çözme etkinlikleri, grup problem çözme etkinlikleri, yarı yapılandırılmış görüşme formu, video ve ses kaydı kullanılmıştır. Elde edilen veriler betimsel analiz yaklaşımı kullanılarak çözümlenmiştir. Öğrencilerin süreç boyunca nasıl yansıtma yaptıklarını incelemek için Hong ve Choi'nin (2011) çalışmalarında oluşturmuş olduğu üç boyutlu kuramsal çerçevenin yansıtmanın konusu ile ilgili olan bilgi, deneyim, his/duygu, bağlam ve grup arkadaşı şeklindeki beş teması alınmıştr. Araştırma sonucunda öğrencilerin bilgi, deneyim ve bağlam temalarında başarılı yansıtmalar ortaya koydukları belirlenmiştir. Buna ek olarak, öğrenciler his/duygu ve grup arkadaşı temalarında da yansıtmalar yapabilmiştir. Tüm bunlara rağmen, öğrencilerin çeşitli göstergeler dâhilinde yansıtma yapmakta zorlandıkları, eksik yansıtma yaptıkları veya herhangi bir yansıtma yapamadıkları durumların olduğu da görülmüştür.

Anahtar Kelimeler: problem çözme, yansıtıcı düşünme becerisi, yansıtma

\section{Abstract}

The The aim of this research is to examine the reflective thinking skill of students with good mathematical problem-solving skill with respect to general problem solving. A qualitative research technique, case studying, was used in this study. Three students who were good at solving math problems were participants in this research. Individual problem-solving activities, group problem-solving activities, semi-structured interviews, and video and voice recordings were used as data collection tools. Received data were analyzed by using a descriptive analysis approach. To analyze how the students perform reflection during the examination process, a conceptual framework was used for descriptive analysis by considering five factors, such as knowledge, experience, feeling/emotion, context, and a group friend. These factors correspond to the reflection in a three-dimensional theoretical framework that Hong and Choi (2011) introduced in their studies. As a result of the research, it has been determined that the students have successfully reflected on the themes of knowledge, experience and context. In addition, students were able to reflect on feelings / emotions and group-friend themes. Despite all these, it has also been seen that students had difficulty in make reflection, they make indeficient reflection or they couldn't make any reflections within various indications.

Keywords: problem solving, reflective thinking skill, reflection

1. Bu çalışma, ikinci yazarın birinci yazar danışmanlığında gerçekleştirilmiş yüksek lisans tezinden üretilmiştir.

2. 31 Mayıs - 3 Haziran 2016 tarihlerinde Muğla Sıtkı Koçman Üniversitesi'nde gerçekleştirilen 3.Uluslararası Avrasya Eğitim Araştırmaları Kongresi'nde sözlü bildiri olarak sunulmuştur.

3. Marmara Üniversitesi, Atatürk Eğitim Fakültesi, Matematik ve Fen Bilimleri Eğitimi Bölümü, İstanbul, Türkiye; https://orcid.org/0000-0003-4755-4089

4. Milli Eğitim Bakanlığı, Yalıköy Ortaokulu, Trabzon, Türkiye; https://orcid.org/0000-0002-0400-3140

Atff / Citation: Pusmaz, A., \& Tavşan, S. (2019). Problem çözmede başarılı öğrencilerin problem çözmeye yönelik yansıtıcı düşünme becerilerinin incelenmesi. Kastamonu Education Journal, 27(2), 837-852. doi:10.24106/kefdergi.2887 


\section{Extended Summary}

Purpose: According to Shermis (1992) "Reflective thinking skill (RTS) is best observed in the problem solving process, and RTS's aim is to find the most appropriate solution when encountering a problem." (p.51). RTS toward problem solving (RTSTPS), revealed by these thoughts, is a mental activity that is consciously performed during the problem-solving process. This mental activity influences the individual's movements, ideas, emotions, and feelings concerning a given problem situation (Hong and Choi, 2011). When previous literature is examined, it can be seen that some of the studies related to RTSTPS are aimed at improving the scale (K1z1lkaya and Askar, 2009; Hong and Choi, 2015), whereas others involve students (Bas and Kiv1lc1m, 2011; Sen, 2013; Saygllı and Atahan, 2014; Demirel, Derman, and Karagedik, 2015, Günes, 2015; Tat, 2015), preservice teachers (Baki, Güc, and Ozmen, 2012; Tuncer and Ozeren, 2012; Can, 2015), and students of the engineering faculty (Adams, Turns, and Atman, 2003; Hong, 2011). When the studies were examined, it was seen that these usually were quantitative studies that investigated the relation between RTSTPS and different variables. It was determined that whereas study groups of qualitative studies mostly comprised university students, the sample groups of the quantitative studies usually comprised primary and secondary students. It is considered necessary to conduct qualitative studies that examine this process in detail to better understand how the students who have good math problem-solving skills reflect during problem solving. Therefore, the aim of this research is to examine the RTS that students with good math problem-solving skill possess that is related to general problem solving. In this context, an attempt has been made to determine how students can reflect in the problem-solving process within the context of the determined themes.

Method : A case study, a qualitative research method, was used in this study. Because expert problem solvers are the most suitable participants and more data can be obtained from the students, the purposive sampling method was used. Three students who were good at solving math problems were the participants of the research. In line with research ethics, Alp, Bora, and Cenk pseudonyms were used instead of real names. Alp, among the students who have shown high academic achievement and actively participate in the class, has a calm personality as well as a high level of association and interpretation; Bora has a structure indicating a high level of association and interpretation and that which shows he is enterprising; and Cenk has a silent structure besides a love for working independently. Individual problem-solving activities (IPSA), group problem-solving activities (GPSA), semi-structured interviews, and video and voice recordings were used as data collection tools. When the IPSA was applied, the students individually solved the problems and clinical interviews were conducted with the students during this process. A few days after the initial IPSA were undertaken by all the students, the students joined the initial GPSA in groups of three. The application was repeated in this way for other problems. All problem-solving activities were recorded using a video recorder. After the completion of the problem-solving activities, semi-structured interviews were conducted with each student, and these interviews were recorded with a voice recorder. After transcribing the video and audio recordings, the resulting data were analyzed via descriptive analysis. To analyze how the students reflected during the process, the conceptual framework was used for descriptive analysis by considering five factors, which are knowledge, experience, feeling/ emotion, context, and group friend, about the reflection of three-dimensional theoretical framework that Hong and Choi (2011) have introduced in their studies. Depending on the thematic framework, data were examined and edited.

Results and Discussions: During summarizing the examined cases, instead of reflecting in their own type of language, students read the problem again and chose to present information in the problem in a similar language to that used in the problem. Similarly, in their study, Aydemir and Kubanç (2014) have determined that some students preferred to read the problem again instead of explaining it in their own words. It is observed that to solve GPSA, students have preferred to use a strategy that has been used in a problem that they have encountered earlier and they presented a corresponding pattern of reflection. Polya (1957) has stated that in similar situations, problem solvers remembered similar problems they solved previously and applied similar strategies. Findings reached as a result of the research are similar to the results of this study. In formulating solutions to the problems, reflections on not only students' experience but also on their mathematical knowledge have been effective. Likewise, in his study, Kitchener (1983) has noted that experiences as well as knowledge are necessary for students to formulate possible solutions. Students have been able to formulate a problem similar to the problems given for reflection in the process. Generally, they have been able to make a similar problem by changing the numerical values without changing the contexts and conditions of the given problem. Similarly, in their study, Tertemiz ve Sulak (2013) have reached the conclusion that most of the students formulated their new problem by changing the numerical data in the given problem. As a result of this research, students were found to be generally good not only at knowledge, experience, and context themes but also at presenting reflections on feeling/emotion and group friend themes. However, in some cases these students found it difficult to reflect within the specified indicators and it was found that they could make in deficient reflection or they could not reflect at all. 


\section{Giriş}

Günümüzde matematik eğitim anlayışı; karşılaştğı problemlere çözümler üretebilme ve bu süreçteki akıl yürütmelerini ifade edebilme, tahminlerde bulunabilme, kanıta dayalı çıkarımlar yapabilme, kendi öğrenme ve düşünme süreçlerini yönetebilme gibi üst düzey becerilere sahip bireyler yetiştirmeyi amaçlamaktadır (Milli Eğitim Bakanlığı, [MEB], 2018). Bu üst düzey düşünme becerilerinden biri, sorgulamalar yaparak deneyimlerin yeniden yapılandırılmasına olanak tanıyan yansıttcı düşünme becerisidir (Mahnaz, 1997). Yansıtıcı düşünme becerisi (YDB); bireyin karşılaşthğı sorunlar için birçok düşünce ortaya koyabilmesi, geçmiş ve şimdiki deneyimlerini kullanarak ortaya koyduğu bu düşünceleri sorgulayabilmesi ve değerlendirmeler yapabilmesi; diğer bir deyişle karşılaştı̆ı̆ sorunları çözebilmek için neler yapabileceğini düşünebilmesi olarak tanımlanabilir (Kember vd., 2000).

YDB sayesinde birey; duygularını, hislerini, tutumlarını, düşünce ve değerlendirmelerini yansıtarak problemlere bulduğu çözüm yollarını görmekte ve çözümün uygunluğunu değerlendirerek tekrar yapılandırma yapabilmektedir (Ersözlü, 2008). Bu görüşe paralel olarak, bazı araşttrmacılar YDB ile problem çözme sürecini ilişkilendirmişlerdir. Ferri'ye (2003) göre YDB bir problemle karşılaşıldığında sonucun ne olduğunu bulmaktan ziyade, problemin çeşitli boyutlarıyla ele alınıp incelenmesiyle ilgilidir. Bu düşünme becerisi, problem çözme sürecinde ortaya konulan varsayımların değerlendirilmesini de içermektedir (Mezirow, 1991). YDB, problem için ortaya konan çözüm yollarının değerlendirilmesine ve en iyi çözüm yolunun seçilmesine olanak tanımaktadır (Bingham, 2004). Tripp’e (2003) göre ise yansıtıcı düşünme, problemin tanımlanmasıyla başlar, ardından problem bağlamında neler yapılabileceği listelenir ki yansıtıcı düşünme asıl bu aşamada gerçekleşir, sonrasında uygulama için plan yapılır ve plan uygulamaya konulur, yapılanlar açıklanarak değerlendirilir ve bu süreç tekrar yansıticı düşünme ile başa dönen bir döngüyle devam etmektedir. Tüm bu düşüncelerden hareketle ortaya konan problem çözmeye yönelik yansıttcı düşünme becerisinin (PÇYYDB), problem çözme aşamalarında yapılan yansıtmaların birleşiminden oluştuğu söylenebilir. Diğer bir deyişle PÇYYDB, "Problem çözme sürecinde problemin anlaşılmasından çözülmesine kadar gerçekleştirilen, odaklanma, planlama, olası çözümler üretme, karar alma ve değerlendirme aşamalarında yansıtıcı düşünme tarzının hâkim olduğu bir üst düzey düşünme biçimidir." (Saygılı ve Atahan, 2014, ss.182-183).

Hong ve Choi (2011) öğrencilerin problem çözüm süreçlerinde bilgi, deneyim, his/duygu, bağlam ve grup arkadaşı olmak üzere farklı konularda yansıtmalar yaptıklarını ifade etmiştir. Belirtilen bu yansıtma konularının problem çözme sürecinde önemli rol oynadığı, araştırmacılar tarafindan çeşitli şekillerde belirtilmiştir. Başarılı bir şekilde problem çözebilmek için problem çözme ile ilgili ön bilgilere sahip olmak gerekmektedir. Diğer bir deyişle bir öğrencilerin karşısına çıkan veya çıkabilecek problemleri çözebilmesi için çoklu bilgi parçacıklarına sahip olması gerekmektedir. Bununla birlikte, bir öğrencinin sadece gerekli matematiksel bilgileri bilmesi bir problemi çözebilmesi için yeterli değildir, aynı zamanda verilen-istenenleri belirleyebilme, problemi özetleyebilme gibi konularda da donanımlı olması gerekmektedir (Hong, 2011). Öğrencilerin problem için olası çözümler üretebilmesinde önceki deneyimlerini göz önünde bulundurmasının etkisi büyüktür. Mevcut deneyimleri ile karşılaştığı durum arasında benzerlik ve farklılıkları belirleyerek kıyaslamalar yapabilmesi problem çözme becerilerini geliştirme hususunda çok önemlidir (Ahmed, Wallace ve Blessing, 2003). Deneyimlerine bağlı olarak problemdeki ilgili veya ilgisiz verileri, eksik veya fazlalık olarak verilen ifadeleri belirleyebilmeleri problemi daha rahat bir şekilde çözebilmelerine yardımcı olabilmektedir. Öğrencilerin ortaya koyduğu farklı çözüm yollarından kendilerine göre iyi olanı belirleyebilmeleri bağlamında deneyim kazanmaları, gelecekte karşılaşabilecekleri problemlere karşı çözüm süreçlerinde önemli rol oynamaktadır (Visscher-Voerman ve Procee, 2007). Bununla birlikte, öğrencilerin problemi ilk kez okuduğunda çözebileceğini veya çözemeyeceğini hissetmesi, problemi çözemeyeceğini düşündüğü için korku duyması, tedirgin veya mutlu olması, problemi veya problem çözme sürecini sıkıcı bulması veya sürecinin hoşuna gitmesi gibi durumlar da problem çözme performanslarını etkileyebilmektedir (Hong ve Choi, 2015). Moallem (1998) ise öğrencilerin, problemin zorluk düzeyi ve içeriğinin yanı sıra bulduğu sonucun doğruluğuna ilişkin yorumlarının da çözüm sürecini etkilediğini dile getirmiştir. Hong (2011) tüm bunların yanı sıra problem çözüm sürecinde öğrencilerin grup arkadaşlarının görüşleri üstünde düşünmesinin de önem taşıdığını belirtmiştir. Diğer bir deyişle,, grup arkadaşlarının görüşleri üzerinde yansıtma yapabilen öğrencinin, önceki kararlarını veya seçtiği stratejileri değiştirebildiğini, grup arkadaşlarının fikirlerine katılabildiğini veya bu fikirleri zenginleştirebildiğini vurgulamıştır.

Alan yazın incelendiğinde PÇYYDB bağlamında yapılmış birçok çalışmaya ulaşılmıştır. Ulaşılan bu çalışmalardan bazılarının ölçek geliştirmeye yönelik olduğu (Kızılkaya ve Aşkar, 2009; Hong ve Choi, 2015), bazılarının ise öğrenciler (Baş ve Kıvılcım, 2011; Şen, 2013; Saygılı ve Atahan, 2014; Demirel, Derman ve Karagedik, 2015; Güneş, 2015; Tat, 2015); öğretmen adayları (Bjuland, 2004; NG ve Tan, 2006; Baki, Güç ve Özmen, 2012; Tuncer ve Özeren, 2012; Can, 2015) ve mühendislik eğitimi alan öğrenciler (Adams, Turns ve Atman, 2003; Hong, 2011) üzerine odaklandıkları görülmektedir.

Öğrencilerle yapılan çalışmalar incelendiğinde; Saygııı ve Atahan'ın (2014), üstün zekalı öğrencilerin problem çöz- 
meye yönelik yüksek düzeyde yansıtıcı düşünme becerisine sahip olduklarını belirlediği görülmüştür. Benzer şekilde Güneş (2015) de bilim ve sanat merkezlerinde öğrenim gören öğrencilerle çalışmış ve 7. sınıf öğrencilerinin matematik dersine yönelik tutumları ile PÇYYDB'leri arasında anlamlı bir ilişki olduğunu ifade etmiştir. Demirel, Derman ve Karagedik (2015) de 7. ve 8. sınıf öğrencilerinin matematiğe yönelik tutumları ile PÇYYDB'leri arasındaki ilişkiye odaklanmış ve bu iki değişken arasında orta derecede anlamlı bir farklılık olduğunu ortaya koymuştur. Baş ve Kıvılcım (2012) ise lise öğrencilerinin geometri ders başarısı ile PÇYYDB arasındaki ilişkiyi incelemiş ve bu iki değişken arasında yüksek pozitif bir ilişki olduğunu belirlemiştir. Tat (2015) ortaokul öğrencileri ile öğretmenlerini bir arada ele almış ve öğrencilerin PÇYYDB'leri ile öğretmenlerin problem çözme basamaklarına dair bilgi düzeyleri, yansıtıcı düşünme eğilimleri arasında pozitif yönde bir ilişki olduğu sonucuna ulaşmıştır. Şen (2013) ise, 7. sınıf öğrencilerinin PÇYYDB'leri ile ailelerinin gelir düzeyi arasında pozitif yönde anlamlı bir farklııı olduğunu belirtmiştir.

PÇYYDB ile farklı değişkenler arasındaki ilişkinin araştrıldığı çalışmaların genellikle nicel araştırmalar olduğu görülmüştür (Baş ve Kıvılcım, 2011; Tuncer ve Özeren, 2012; Şen, 2013; Saygılı ve Atahan, 2014; Can, 2015; Demirel, Derman ve Karagedik, 2015; Güneş, 2015; Tat, 2015). Bu çalışmaların örneklemlerinin ise genellikle ilköğretim ve ortaöğretim düzeyindeki öğrenciler olduğu (Baş ve Kıvılcım, 2011; Şen, 2013; Saygılı ve Atahan, 2014; Demirel, Derman ve Karagedik, 2015; Güneş, 2015; Tat, 2015), nitel çalışmaların ise çoğunlukla üniversite öğrencilerine (Adam, Turns ve Ataman, 2003; Bjuland, 2004; NG ve Tan, 2006; Hong, 2011; Baki, Güç ve Özmen, 2012) odaklandığı tespit edilmiştir. Dewey'in (1933) dediği gibi öğrencilerin problemin çözümüne yanıt ararken veya çözüme ilişkin farklı bir bakış açısı geliştirirken sorgulama yapabilmesi, yapılanları bir nedene dayandırabilmesi, ihtiyaç duyulan ve sahip olunan bilgiyi değerlendirmesi, bireyin öğrenmelerinin etkililiğini sağlaması açısından çok önemlidir. Ayrıca ilköğretim düzeyindeki öğrencilerin küçük yaşta, problem çözme sürecindeki yansıtıcı düşünme becerilerinin incelenmesi, var olan durumlarının ortaya konabilmesi ve eksikliklerini tamamlamaya yönelik çalışmalar yapııması onların gelecek hayatlarında karşılaşabilecekleri sorunlara etkili çözümler bulabilmeleri hususunda onlara yardımcı olabilmek adına gerekli ve önemli bir ihtiyaç olarak görülmektedir. Bu bağlamda, bireylerin problem çözme esnasında yansıtıcı düşünme sürecini ayrıntılı olarak incelemeye olanak tanıyan nitel çalışmaların yapılması önemlidir. Tüm bu nedenlere bağlı olarak yapılan bu çalışmada matematik problemlerini çözmede başarılı öğrencilerin PÇYYDB'lerinin nasıl olduğu incelenmiştir. Bu kapsamda, öğrencilerin bireysel ve grup halindeyken problem çözme sürecinde belirlenen temalar bağlamında nasıl yansıtma yapabildikleri belirlenmeye çalışılarak şu sorulara cevap aranmıştir:

1. Problem çözmede başarılı öğrencilerin bireysel olarak problem çözerken sergilemiş oldukları yansıtıcı düşünme becerileri nasıldır?

2. Problem çözmede başarılı öğrencilerin grup olarak problem çözerken sergilemiş oldukları yansıtıcı düşünme becerileri nasıldır?

\section{Yöntem}

\section{Araştırma Deseni}

Araştırmada nitel araştırma modellerinden biri olan özel durum çalışması kullanılmıştır. Özel durum çalışması "olayı gerçekleştiği doğal ortamında derinlemesine gözlemlemeye, sistematik bir biçimde veri toplamaya, analiz etmeye, sonuçları ortaya koymaya olanak sağlamasının yanı sıra özellikle bireysel olarak yürütülen çalışmalar için uygun olması" (Çepni, 2009, s.66) nedeniyle bu araştırma için uygun bir modeldir.

\section{Çalışma Grubu}

Çalışma grubu, amaçlı örnekleme yöntemlerinden benzeşikörnekleme yöntemi ile seçilmiştir. Benzeşikörneklemede amaç küçük, benzeşik bir örneklem oluşturma yoluyla belirgin özelliklere sahip bir alt grubu tanımlamaktır (Yıldırım ve Şimşek, 2013).

Araştırmanın çalışma grubunu Trabzon ilindeki bir ortaokulda öğrenim gören, matematik problemlerini çözmede başarılı üç sekizinci sınıf öğrencisi oluşturmaktadır. Çalışma grubu oluşturulurken öğrencilerin okuduğunu anlayabilme, yorum yapabilme, duygu ve düşüncelerini sözel olarak rahatlıkla ifade edebilme, arkadaşlarıyla etkili iletişim kurabilme, verilen durumu yorumlama, karşılaşılan probleme alternatif çözümler sunabilme, ilişkilendirme yapabilme gibi hususlardaki durumları hakkında öğretmenlerinden görüş alınmıştır. Ayrıca matematik derslerindeki akademik başarıları ve problem çözme becerileri de dikkate alınarak gönüllü üç erkek öğrenci çalışma grubuna seçilmiştir.

Çalışmada araştırma etiği açısından öğrencilerin gerçek isimleri yerine Alp, Bora ve Cenk şeklinde takma isimler kullanılmıştır. Akademik başarıları yüksek ve derse aktif bir şekilde katılmakta olan bu öğrencilerden Alp ilişkilendirme 
ve yorum gücü yüksek olmasının yanı sıra sessiz; Bora ilişkilendirme ve yorum gücü yüksek, girişken; Cenk ise bağımsız çalışmayı sevmesinin yanı sıra sessiz bir yapıya sahip öğrencidir.

\section{Veri Toplama Araçları ve Verilerin Toplanma Süreci}

Veri toplama aracı olarak bireysel problem çözme etkinlikleri (BPÇE), grup problem çözme etkinlikleri (GPÇE), yarı yapılandırılmış görüşme formu, video ve ses kaydı kullanıımıştır.

BPÇE ve GPÇE'nin hazırlanmasında öncelikle ilgili literatür taranmış (makaleler, ulusal ve uluslararası değerlendirme çalışmalarının raporları, matematik ders ve çalışma kitapları) ardından birden fazla stratejiyle çözülmeye uygun 10 tane rutin olmayan problem araştırmacılar tarafindan oluşturulmuştur. Problemlerin, öğrenci seviyesine uygunluğuna, rahatlıkla anlaşıır olup olmadığına, birden fazla strateji ile çözülebilir olup olmadığına yönelik matematik eğitimi alanında uzman üç akademisyenden görüş alınmıştr. Uzman görüşleri doğrultusunda araştırmada kullanılmak üzere BPÇE ve GPÇE için hazırlanan problemler arasından üçer problem seçilmiştir. Bunlardan BPÇE için hazırlanan Saksıdaki Çiçekler ve GPÇE için hazırlanan Taksi problemleri Şekil 1 ve Şekil 2'de verilmiştir.

\begin{tabular}{|c|c|c|}
\hline \multicolumn{3}{|c|}{$\begin{array}{l}\text { Mehmet Amca'nı sadece saksıda yetişen çiçekleri } \\
\text { dükkânı vardır. Çiçekleri müşteriler kendileri gelip } \\
\text { gibi, adrese teslim de yapılmaktadrr. Mehmet Am } \\
\text { satışlarda çiçek başna aşağıdaki fiyat tarifesini uygul } \\
\text { (Not: Her saksıda sadece bir çiçek bulunmaktadır. }\end{array}$} \\
\hline & $\begin{array}{c}\text { Adrese teslim } \\
\text { edilirse }\end{array}$ & $\begin{array}{c}\text { Müșteri gelip } \\
\text { ahırsa }\end{array}$ \\
\hline $\begin{array}{c}\text { Müșteri saksı } \\
\text { getirirse }\end{array}$ & $1,4 \mathrm{TL}$ & $1,5 \mathrm{TL}$ \\
\hline $\begin{array}{l}\text { Müșteri saksı } \\
\text { getirmezse }\end{array}$ & $1,65 \mathrm{TL}$ & $1,8 \mathrm{TL}$ \\
\hline \multicolumn{3}{|c|}{$\begin{array}{l}\text { Bir müşteri Mehmet Amca'ya } 5 \text { adet saksı getimiş ve aldığ } 1 \\
\text { çiçeklerin adrese teslim edilmesini istemiştir. Mehmet Amca'ya } \\
40 \text { TL ödeyen müşteri kaç tane çiçek satm almış olur? }\end{array}$} \\
\hline
\end{tabular}

\section{Şekil 1. Saksıdaki Çiçekler Problemi}

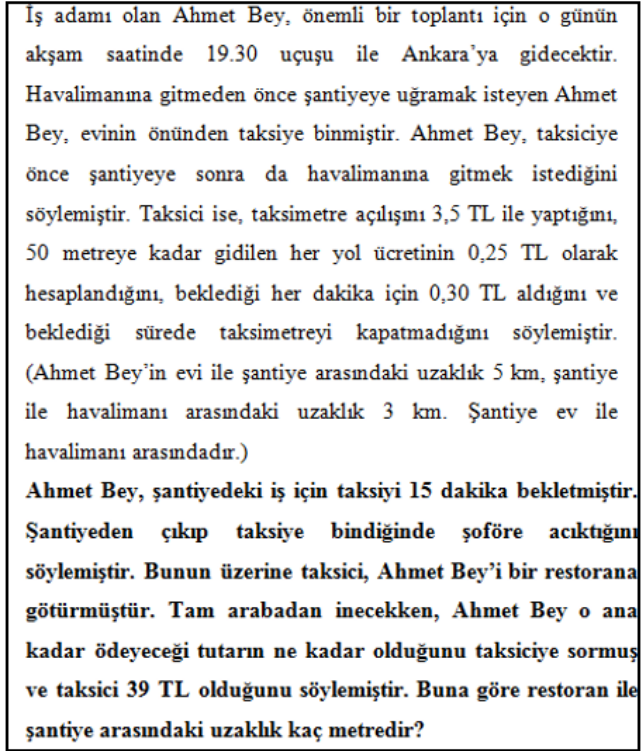

Şekil 2. Taksi Problemi

BPÇE uygulanırken öğrenciler bireysel olarak problemleri çözmüşler ve bu süreçte öğrencilerle klinik mülakatlar yapılmıştır. BPÇE'nin birincisi tüm öğrencilere uygulandıktan birkaç gün sonra öğrenciler üç kişilik grup halinde GPÇE'nin birincisine katılmışlardır. Uygulama bu şekilde diğer problemler için de tekrarlanmıştır. Tüm problem çözme etkinlikleri video kayıt cihazı ile kaydedilmiştir.

Problem çözme etkinliklerinin tamamlanmasından sonra her bir öğrenciyle yarı yapılandırılmış görüşmeler yapılmış ve bu görüşmeler ses kayıt cihazı ile kaydedilmiştir. 18 soruluk yarı yapılandırılmış görüşme formu, öğrencilerin problem çözme etkinliklerinde yaşadıkları duyguları, hisleri ortaya çıkartmak, problem çözme süreçlerini değerlendirmelerini belirlemek amacıyla ilgili literatürden yararlanılarak hazırlanmış ve üç uzmanın görüşleri alınarak son hali elde edilmiştir. Görüşme formunda bulunan sorulardan bazıları Tablo 1'de verilmiştir.

\section{Tablo 1. Görüşme formu soru örnekleri}

\begin{tabular}{cl}
\hline Sorunun bağlamı & \multicolumn{1}{c}{ Görüşme formundaki soru örneği } \\
\hline Deneyim & $\begin{array}{l}\text { Daha önce, sana verilen probleme benzer bir problemle karşılaşmış olman problem çözüm sürecine ne gibi } \\
\text { katkılar sağladı? }\end{array}$ \\
Bağlam & $\begin{array}{l}\text { Çalışma süresince size verilen alt problem durumunu zorluk düzeyi bakımından karşılaştırdığında neler } \\
\text { söyleyebilirsin? }\end{array}$ \\
Duygu/His & $\begin{array}{l}\text { Çalışma süresince karşına çıkan alt problem durumundan hangisini çözmek seni daha çok mutlu etti? Ne- } \\
\text { den? }\end{array}$ \\
Uygulama Süreci & $\begin{array}{l}\text { Bireysel/Grup olarak cevap verdiğin(iz) üç problem durumu için çözüm planı oluşturabilme hususunda } \\
\text { yaşadığın zorluklar varsa bu zorlukları ifade edebilir misin? }\end{array}$ \\
\hline
\end{tabular}




\section{Verilerin Analizi}

Problem çözüm süreçlerindeki video kayıtları yazılı metine dönüştürüldükten sonra elde edilen veriler betimsel analiz yaklaşımı kullanılarak çözümlenmiştir. Çözümleme aşamasında yapılanlar sırasıyla şu şekildedir (Yıldırım ve Şimşek, 2013):

(i) Betimsel analiz için bir çerçeve oluşturulması: Öğrencilerin problem çözme sürecinde nasıl yansıtma yapabildiklerini incelemek için Hong ve Choi'nin (2011) oluşturmuş olduğu kuramsal çerçevedeki yansıtmanın konusu ile ilgili olan bilgi, deneyim, bağlam, his/duygu ve grup arkadaşı şeklinde beş teması kullanılmıştır. Bilgi, deneyim, his/duygu ve grup arkadaşı temalarının belirleyicileri oluşturulurken Hong ve Choi'nin görüşlerine bağlı kalınmış fakat araştırma için makul bulunmadığından dolayı bağlam temasının belirleyicileri ise iki uzmanın ortak görüşleri doğrultusunda oluşturulmuştur. Veriler analiz edilirken sırasıyla B, D, BA, H ve G şeklinde kodlanmıştır. Böylelikle veri analizi için bir çerçeve oluşturularak verilerin hangi temaların altında sunulacağı belirlenmiştir (Tablo 2 ).

(ii) Verilerin işlenmesi: Bu aşamada, bir önceki aşamada oluşturulan tematik çerçeveye bağlı olarak veriler düzenlenmiş; temaların göstergeleri doğrultusunda, öğrencilerin belirlenen göstergeleri ortaya koyabilme durumlarının nasıl olduğuna bakılmıştır. Öğrencilerin süreç içerisindeki yansıtmaları incelendiğinde, önemli görülen bazı yansıtmaların daha önce oluşturulan göstergeler kapsamında ele alınamadığı görülmüş ve uzman görüşü de alınarak D9 ve D10 maddeleri de deneyim bağlamındaki göstergeler arasına eklenmiştir.

Eğer öğrenci, bilgi, deneyim ve bağlam temalarına ait göstergeleri süreç boyunca tam anlamıyla gösterebilmiş ise başarılı bir şekilde yansıtma yapabildiği (3 puan), eksik olarak gösterebilmiş ise yansıtmasında eksiklikler olduğu (kısmen eksik ise 2, tamamen eksik ise 1 puan) belirtilmiştir. Örneğin; bir problemin çözüm sürecinde herhangi bir göstergeye yönelik 10 yansıtma sergilemiş ve bunların her biri başarılı yansıtmalar olan bir öğrencinin bu problem için ilgili gösterge kapsamındaki durumu 3 puan olarak değerlendirilmiştir. Eğer öğrencinin başarılı yansıtmaları 5 (ortaya koyduğu yansıtma sayısının yarısı) ila 9 arasında ise bu gösterge kapsamındaki durumu 2 puan, başarılı yansıtmalarının sayısı 5 'ten daha az ise durumu 1 puan olarak değerlendirilmiştir. Eğer öğrenci ilgili gösterge çerçevesinde herhangi bir yansıtma yapamamış ise durumu 0 puan olarak değerlendirilmiştir.

Öğrencilerin problem çözüm süreçleri içerisinde duygusal anlamda dile getirdikleri ifadeler his/duygu teması kapsamında ele alınmıştır. Grup teması kapsamında yapılan yansıtmalar ise, öğrencilerin grup halinde problem çözerken (GPÇE) sergiledikleri davranışlar sonucu ortaya çıkmıştır. Ayrıca yukarıda belirtilen göstergeler çözüm sırasında öğrenciler tarafından başarılı bir şekilde yansıtıımışsa parantez içerisinde göstergenin kodu yazılarak sunulmuştur. Göstergeler eksik bir şekilde sergilenmişse kodun önüne eksi işareti konulmuştur.

(iii) Bulguların tanımlanması: Bu aşamada elde edilen veriler düzenlenerek gerekli görüldüğü yerlerde doğrudan alıntılar yapılarak bulgular başlığı altında betimsel olarak sunulmuştur.

(iv) Bulguların yorumlanması: Bu aşamada tanımlanan bulgular açıklanarak birbirleriyle ilişkilendirilmiştir. Gerekli görüldüğü yerlerde kathlımcıların durumları karşılaştrılmıştr.

Öğrencilerle yapılan görüşmelerden elde edilen ses kayıtları yazılı metine dönüştürüldükten sonra, ortaya çıkan veriler doğrudan alıntılarla sunulmuştur. 


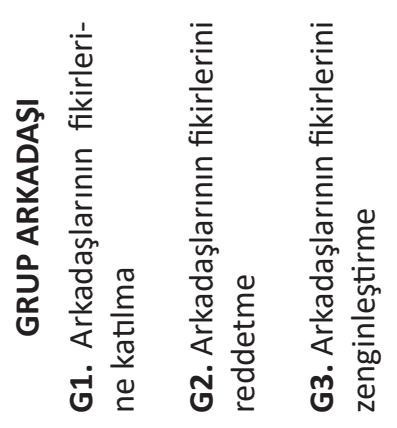

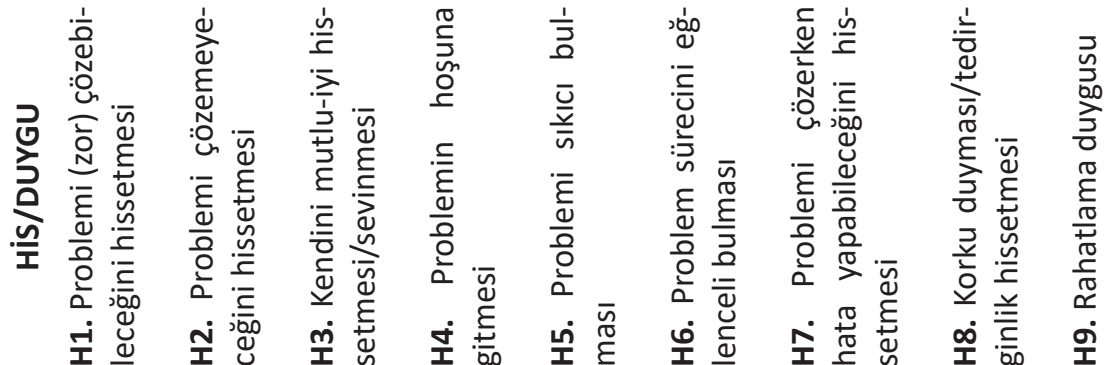

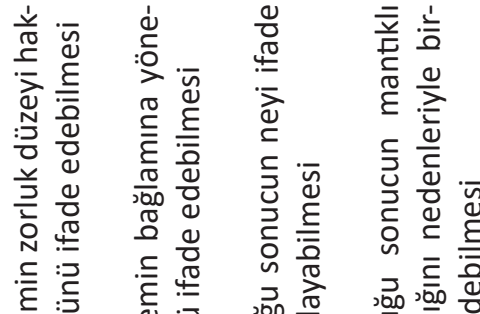

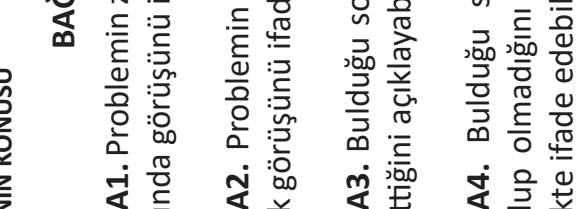

\section{$\overline{\bar{N}} \quad \frac{\pi}{\overline{0}} \cdot \frac{1}{\bar{n}}$}

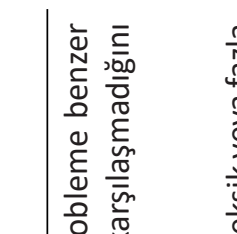

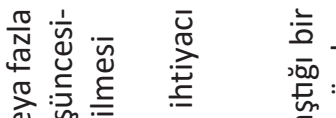

焉:

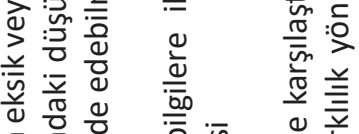

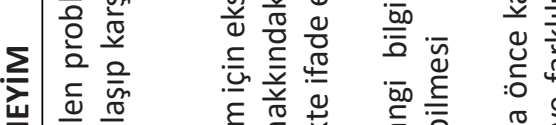

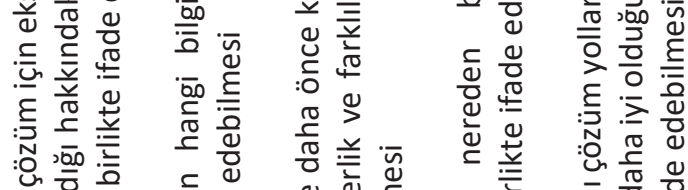

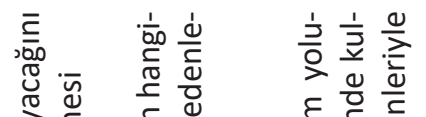

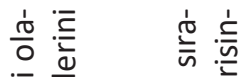

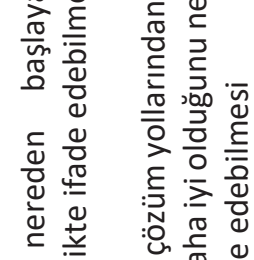

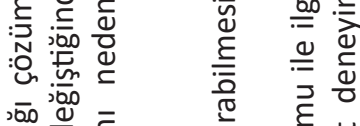

उ

$\stackrel{\frac{5}{5}}{\frac{5}{0}}$

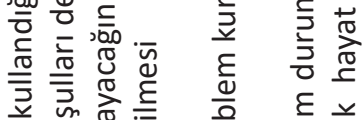

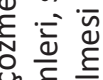

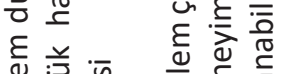

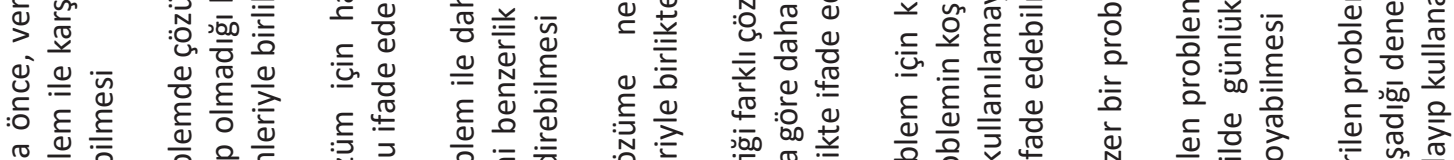

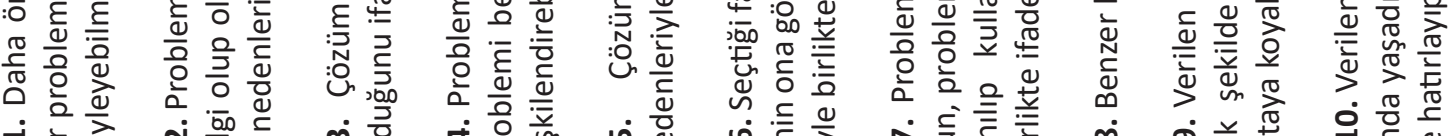

ติ 흥

पे 을

นค่

드릉

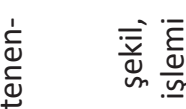

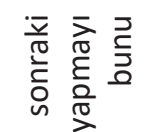

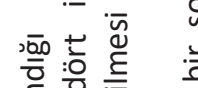

岁

$2 \div$

吕突元言

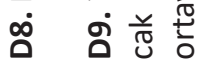

ำ

总咅

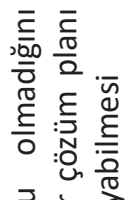

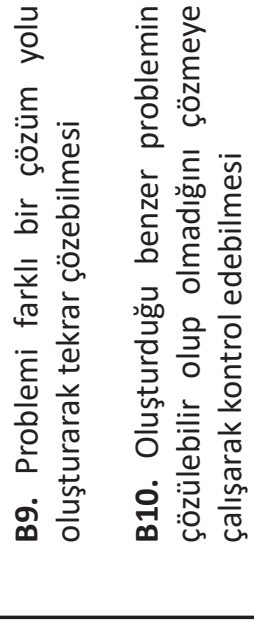

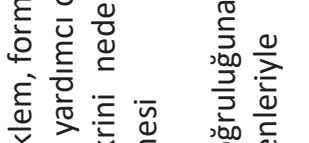

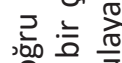

응

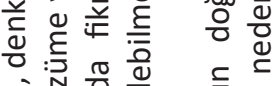

ह

产 :

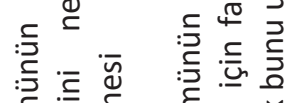

空

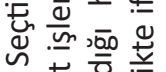

:

है

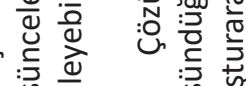

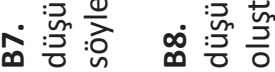


Bu araştırmanın geçerliğini sağlamak amacıyla, uygulama süreci boyunca katılımcılarla ve elde edilen verilerle uzun süreli etkileşim halinde olunmuş, veri toplama araçları çeşitlendirmiş ve oluşturulmasında uzman görüşleri alınmış, verilerin analizi sürecinde gerektiği durumlarda katılımcı teyidine başvurulmuş ve doğrudan alıntılarla veriler sunulmuştur. Benzer şekilde güvenirliği sağlamak için veri analizinde literatür yardımıyla hazırlanan çerçeve kullanılmış, analiz sürecinde yapılan kodlamaların tutarlığını teyit etmek amacıyla uzman görüşüne başvurulmuş, kodlamalarda oluşan farklı bakış açıları tespit edilerek bu durumlar uzmanlarla fikir alış verişinde bulunularak tekrar gözden geçirilmiştir.

\section{Bulgular ve Yorumlar}

Bu bölümde araştırma sürecinde öğrencilere sorulan altı problemden ikisi olan "Saksıdaki Çiçekler Problemi" ve "Taksi Problemi"nden elde edilen bulgulara yer verilmiştir. Bunlardan ilki bireysel ikincisi ise grup olarak çözülen problemlerdendir. Bu çalışma kapsamında öğrencilerin bu iki problemde sergiledikleri yansıtmalardaki güçlü ve zayıf yönler genel olarak diğer 4 problemde de ortaya çıkmıştır ve son bölümde sadece bu iki problemin bulguları değil ortaya çıkan genel durum tartşılacaktır.

\subsection{Saksıdaki Çiçekler Probleminden Elde Edilen Bulgular}

Saksıdaki Çiçekler Problemi, öğrencilerin araşttrma kapsamında bireysel olarak çözdükleri problemlerden ikincisidir. Bu süreç boyunca öğrencilerin bilgi (B), deneyim (D) ve bağlam (BA) temaları kapsamındaki mevcut durumları Tablo 3 'de gösterilmiştir. Tablo 3 incelendiğinde, öğrencilerin bilgi, deneyim ve bağlam temaları kapsamındaki yansıtmalarının puanlanması sonucunda en yüksek toplam puanı Alp'in, en düşük puanı ise Bora'nın aldığı görülmektedir. Bu göstergeler kapsamında alınabilecek en yüksek toplam puan 72'dir. Buna ek olarak, öğrencilerin problemin uygulama sürecinde B5, B6, B8, D2 ve D10 göstergeleri bağlamında herhangi bir yansıtma ortaya koymadıkları; B2, B7, B9, B10, D1, D6, D7, D8, BA1, BA3 ve BA4 göstergeleri kapsamında ise başarılı yansıtmalar yapabildikleri söylenebilir.

Tablo 3. Saksıdaki Çiçekler Probleminin Çözüm Sürecindeki Bilgi, Deneyim ve Bağlam Temaları Kapsamındaki Yansıtmalar

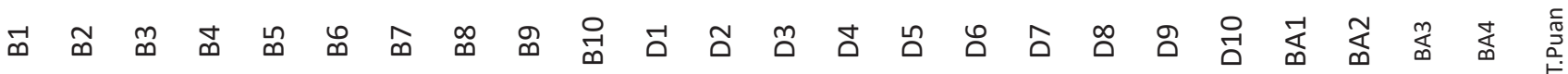

\begin{tabular}{|c|c|c|c|c|c|c|c|c|c|c|c|c|c|c|c|c|c|c|c|c|c|c|c|c|c|}
\hline 0 & 2 & 3 & 2 & 3 & 0 & 0 & 3 & 0 & 3 & 3 & 3 & 0 & 3 & 3 & 3 & 3 & 3 & 3 & 3 & 0 & 3 & 3 & 3 & 3 & 55 \\
\hline סొ & 2 & 3 & 2 & 1 & 0 & 0 & 3 & 0 & 3 & 3 & 3 & 0 & 0 & 0 & 2 & 3 & 3 & 3 & 0 & 0 & 3 & 0 & 3 & 3 & 40 \\
\hline ভ్ & 2 & 3 & 2 & 3 & 0 & 0 & 3 & 0 & 3 & 3 & 3 & 0 & 3 & 0 & 3 & 3 & 3 & 3 & 0 & 0 & 3 & 0 & 3 & 3 & 46 \\
\hline
\end{tabular}

Alp

Alp, Saksıdaki Çiçekler probleminin çözümünde en kapsamlı yansıtmayı sergileyen öğrenci olmuştur. Problemi çözmeye başlarken araştırmacı ile Alp arasında şu diyalog geçmiştir:

Alp: ... Her bir saksıya bir çiçek dikildiğine göre o zaman bu çarpma işlemi ile olur yani 1,4x5=7 lira oluyor (B3, B4). Ama bu 40 lira veriyor ona. O zaman gerisi şeyden olacak. Müşteri saksıyı getirmeyecek, adrese teslim isteyecek. Devamında şimdi 33 lira geriye kaldı, çıkarma yaptım. Saksı getirmediği için geride kalan çiçekler 1,65 liradan hesaplanacak. 33 lirayı 1,65 liraya bölsem çıkar. Bir tanesi bulunur bölme ile (B4-).

Araştırmacı: Sonuç tam çıkar mı sence?

Alp: Yapılır da biraz karışık olur sanki (BA1). Niye bunu 1,65 lira verdi ya. 1,5 verse daha kolay olurdu ama vermemiş. Hiç 1,65 lira olur mu?

Araştırmacı: Neden olmasın peki?

Alp: 1,5 lira olur mesela. Bilmiyorum bizim burada çiçek fiyatları 40 kuruş 65 kuruşlu değil de ondan dedim.

Alp 33 lirayı 1,65 liraya bölmesi gerektiğini söylemesine rağmen, 1,65’e bölme işleminin kendisine karışık geldiğini belirtmiştir (BA1). Ayrıca problemde neden bölme işlemini kolaylaştıracak 1,5 lira gibi bir fiyat verilmediğini sorgulaya-

| Kastamonu Eğitim Dergisi, 27(2), 2019| 
rak "1,65 liraya çiçek olur mu?" şeklinde şaşkınlı̆ıını dile getirmiştir. Araştırmacı Alp’e neden 1,65 lira gibi bir çiçek fiyatı olamayacağını düşündüğünü sorduğunda, Alp yaşadığı çevrede çiçek fiyatlarının 40 kuruş veya 65 kuruşlu bir şekilde olmadığını söylemiştir. Alp'in yansıtmalarına bakıldığında, problemin içeriğinde yer alan sayılara yönelik sorgulayıcı bir bakış açısı içerisinde olduğu ve dolayısıyla BA2 göstergesi kapsamında başarılı bir şekilde yansıtma yapabildiği söylenebilir.

Alp problemi iki farklı yaklaşım (ilki dört işlemin kullanıldığı matematik cümlesi yazma stratejisi, ikincisi ise denklem oluşturma stratejisi) kullanarak çözmüştür. Bunlardan ilkinde 1,4 TL ile 5'i çarparak müşterinin yanında getirdiği saksılara diktireceği çiçekler için ödeyeceği toplam miktarı bulmuştur. Ardından artan parasıyla (40 TL -7 TL = 33 TL) tanesi 1,65 TL den alabileceği çiçeklerin miktarını hesaplamaya çalışmıştı. Bu süreçte ise; önce 1,65 ile 5 i çarpmış ve 8,25 TL elde etmiştir ve ardından 8,25'i çeşitli kereler toplayarak 33'e eşitlemeye çalışmıştır (Şekil 3). Bu stratejisinde bölme işlemi yapmak yerine toplama ile sonuca ulaşmaya çalışmış ve nihayetinde doğru cevap olan 20'ye ulaşmıştır.
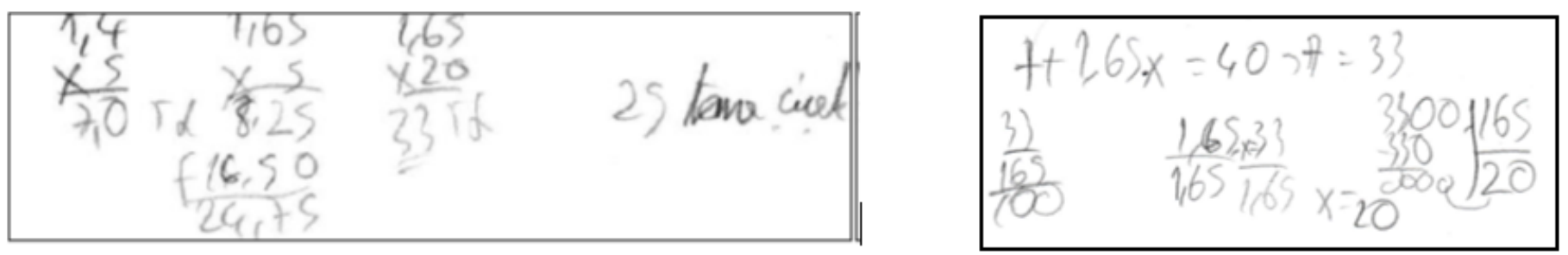

\section{Şekil 3. Alp'in Saksıdaki Çiçekler Problemi için Yaptiğı Birinci (sol) ve íkinci Çözüm (sağ)}

Alp aynı soruya verdiği ikinci cevapta öncelikle bir denklem kurmuş ve bunu çözerken sıra 33'ü 1,65'e bölmeye geldiğinde ilk çözümünde bu işlemin sonucu olarak bulduğu 20'yi kullanmamış ve daha önce yaptığı parçalardan bütüne gitmek yerine bölme işlemi yaparak sonucu bulmaya yönelmiştir. Bir süre düşündükten sonra, 1,65'i kesir çizgisi ile yazabileceğini bu şekilde bölme işlemi yapabileceğini söylemiş ve sonuca ulaşabilmiştir. Alp'in farklı çözüm yolu oluşturabilmeye dayalı açıklamaları incelendiğinde, B9 göstergesi kapsamında başarılı şekilde yansıtma yapabildiği söylenebilir. Alp kendisi ile yapılan görüşme sırasında sorulan "Bireysel olarak cevap verdiğin üç problem durumu için çözüm planını uygulayabilme hususunda yaşadığın zorluklar varsa bu zorlukları ifade edebilir misin?" sorusuna "Saksılı problemde yaşamıştım. 33'ü 1,65'e bölmedeydi bu zorluk. Çünkü bir sayıyı ondalıklıya bölmeyi önceki senelerde görmüştük. Aklıma gelmedi ondan." şeklinde bir cevap vermiştir.

Alp kullandığı stratejilerden ikincisinin kendisine göre daha iyi olduğunu belirtmiş ve neden böyle düşündüğü sorulduğunda "Bence denklem kullanarak çözmek daha zor. Ama denklem oluşturmayla uğraşmak güzel. illk yöntemi herkes yapabilir ama herkes denklem oluşturamaz bence." cevabını vermiştir (D6).

Alp verilen probleme benzer bir problem ile daha önce karşılaşmadığından dolayı problemin ilk başta kendisine zor geldiğini, problemde verilen farklı fiyatları karıştrabileceğini düşündüğü için tedirginlik hissettiğini söyleyerek H8 kapsamında yansıtma yapmıştır. Alp sonucu bulduğunda hissettiklerini ise "Mutlu oldum. Sonuçta yapabildiğimi gördüm. Oh be, sonunda çözebildim diye düşündüm." şeklinde memnuniyetini ifade ederek H3 bağlamında yansıtma ortaya koymuştur.

\section{Bora}

Bora, Saksıdaki Çiçekler probleminin çözümünde diğer iki öğrenciye göre daha az yansıtma yapmıştır. Problemin çözümünde "Problem eğer şu şekilde olsaydı, deminki durum için kullandığın çözüm yolunu bu problem durumu için de kullanabilir miydin? Müşteri saksı getirmeden dükkândan 12 çiçek beğenip ayırtsaydı ve bunları daha sonra kendi gelip alsaydı; aynı koşullara göre saksı getirip ödeyeceği tutardan kaç TL fazla para öderdi?” şeklindeki yönergeyi okumuştur. Bunun üzerine Bora araştırmacıya "Bu problem öbürüne benziyor. Aynı yoldan yapılabilir, çarpma falan." (D7) şeklinde cevap vererek çözmeye başlamıştır (Şekil 4). Bora ilk durumda müşterinin saksı getirmeme durumunu göz önüne almış ve 12 çiçeğin fiyatının 1,8 liradan hesaplanacağını belirterek ücretin 21,6 lira olacağını belirtmiştir. İkinci durumda ise, saksı getirilme durumunu göz önüne alarak çiçeklerin fiyatının 1,5 liradan hesaplanacağını ifade etmiş, bunu 12 ile çarparak 18 lira bulmuştur. 21,6 ile 18'i çıkararak problemin cevabının 3,6 lira olduğunu söylemiştir. 


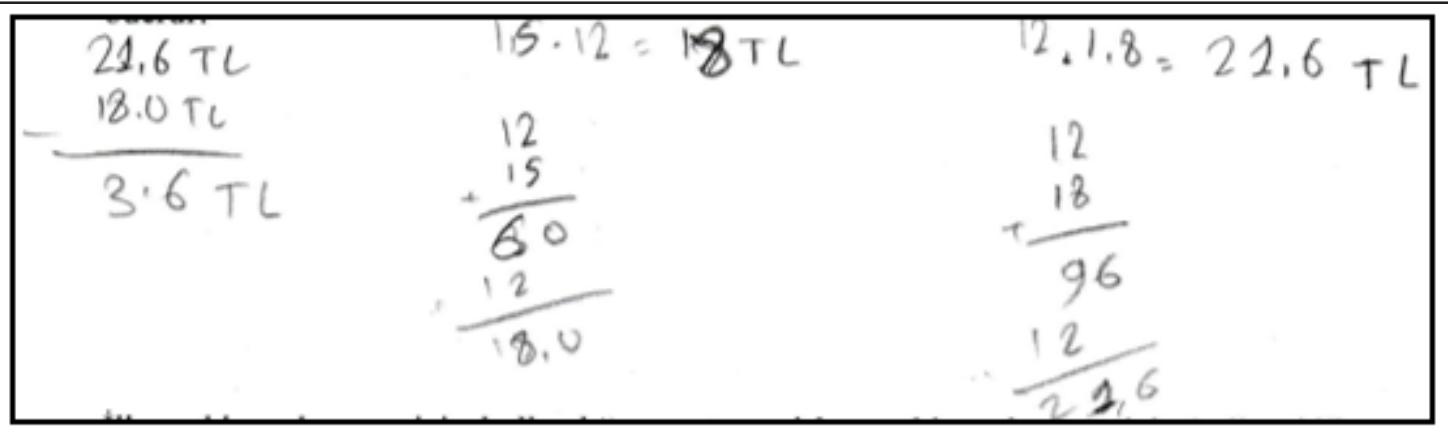

\section{Şekil 4. Bora'nın Değiştirilerek Oluşturulan İkinci Problem Durumuna Yönelik Yaptiğı Çözüm}

Araşttrmacı, Bora'dan Saksıdaki Çiçekler problemine benzer bir problem oluşturması istendiğinde "Bora Bey saksı getirerek 10 tane çiçek beğenmiş ve bunları Mehmet Amca'ya ayırtmıştı. Parkta az işinin olduğunu söyleyerek gitmiş ve daha sonra gelip çiçekleri almıştır. Bora Bey saksı getirip çiçeklerin adrese teslim edilmesini isteseydi ne kadar az para öderdi?" (D8) problemini yazmıştr.

Bora benzer problem oluşturduktan sonra, araştırmacı Bora'dan yazdığı problemin çözülebilir olup olmadığını kontrol etmesini istemiştir. Bunun üzerine, Bora "Saksı getirerek 10 tane çiçek alıyor. Müşteri gelip alıyor. Yani [tablodan bakıyor] 1,5 çarpı 10'dan 15 lira normal borcu. Eee. Bora Bey saksı getirip fakat adrese teslim edilmesini isteseydi dedik 1,4 çarpı 10'dan 14 TL. Yani 15'ten 14'ü çık 1 TL az öderdi?” (B10) şeklinde bir çözüm ortaya koymuştur. Buna ilaveten, araştırmacının "Neden çiçeği 10 tane seçtin?" şeklindeki sorusuna karşılık olarak; "Çünkü 10 ile çarpmak hemen bir virgül kaydırmak demek." şeklinde bir yanıt vermiştir. Bu cevap dikkate alındığında, problemi yazarken kendisine göre çözümü kolaylaştıracak sayıyı önceden belirleyebildiği, diğer bir deyişle problemi yazarken aslında çözümü zihninde kurgulayabildiği söylenebilir.

\section{Cenk}

Saksıdaki Çiçekler problemi bağlamında Alp'ten sonra, en kapsamlı yansıtmayı yapan Cenk olmuştur. Cenk problemi "Bir müşteri Mehmet Amca'ya 5 adet saksı veriyor. Ve aldığı çiçeklerin adrese teslim edilmesini istiyor. Mehmet Amca'ya 40 TL ödedi ve kaç tane çiçek satın aldığını soruyor." (B1-) şeklinde özetlemiştir. Fakat Cenk'in yaptiğı özetlemeye bakıldığında, sorudaki ifadeleri pek değiştirmediği, kendi cümlelerini kullanmadığı görülmüştür. Bu nedenle Cenk'in B1 göstergesi kapsamında eksik bir yansıtma yaptı̆̆ söylenebilir.

Cenk çözüm sürecinde problemde verilen tabloyu yorumlayıp, istenen duruma göre hesaplamada kullanması gereken fiyat bulabilmiş ve yaptığı işlemleri, neden seçtiğini söyleyebilmiştir (B3). Buna ilaveten Cenk, yapttğı işlemleri kontrol ederek bulduğu sonuçtan emin olduğunu belirtmiştir (B7). Cenk de Alp gibi dört işlem kullanarak ilk çözüm yolunu ortaya koymuştur (Şekil 5).

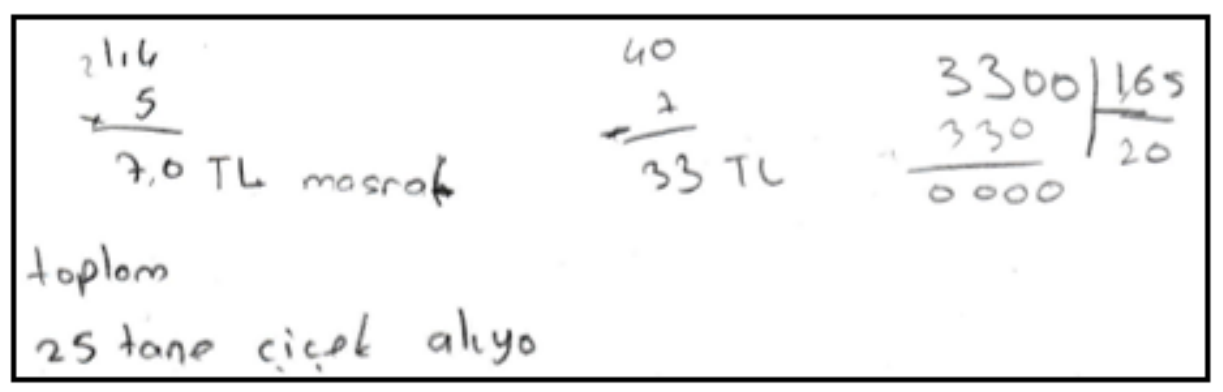

\section{Şekil 5. Cenk'in Saksıdaki Çiçekler Problemi için Yaptığı Çözüm}

İlerleyen süreçte, Cenk problemi ilk çözümünden farklı bir yol ile çözebileceğini belirtmiş ve ikinci bir çözümü denklem kullanarak Alp'in yapttğı gibi ortaya koyabilmiştir (B9). Cenk problem için seçtiği ilk çözüm yolunun kendisine göre daha iyi olduğunu belirtmiştir. Bunun nedenini, denklem kurma ve çözmenin uzun süre alması olarak ifade ederek, D6 bağlamında yansıtma yapmıştır.

\subsection{Taksi Probleminden Elde Edilen Bulgular}

Taksi Problemi, Saksıdaki Çiçekler Problemi'nin bağlamı değişmiş hali olmakla birlikte, öğrencilerin araştrma kapsamında grup olarak çözdükleri problemlerden ikincisidir. Bu süreç boyunca öğrencilerin bilgi, deneyim ve bağlam temaları kapsamındaki yansıtmaları Tablo 4'te gösterilmiștir. Tablo 4 incelendiğinde, en yüksek puanı Bora'nın, en düșük | Kastamonu Eğitim Dergisi, 27(2), 2019| 
puanı ise Cenk'in aldığı görülmektedir. Buna ek olarak, öğrencilerin problemin uygulama sürecinde B5, B6, B8, D9 ve BA2 göstergeleri bağlamında herhangi bir yansıtma ortaya koymadıkları; B7, D1, D6 ve BA1 göstergeleri kapsamında ise başarılı yansıtmalar yapabildikleri söylenebilir.

Tablo 4. Öğrencilerin Taksi Problemi Sürecinde Bilgi, Deneyim ve Bağlam Temaları Kapsamındaki Mevcut Durumları

\begin{tabular}{|c|c|c|c|c|c|c|c|c|c|c|c|c|c|c|c|c|c|c|c|c|c|c|c|c|c|}
\hline & 기 & ๗ & ๓ & ষ & $\stackrel{\llcorner}{\oplus}$ & $\mathscr{\varnothing}$ & $\hat{\infty}$ & $\stackrel{\infty}{\infty}$ & ஜ & 음 & $\stackrel{-1}{0}$ & ธี & ñ & ナั & 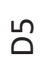 & ڤ̆ & $\hat{\Delta}$ & $\stackrel{\infty}{\circ}$ & ดิ & 음 & $\underset{\infty}{\stackrel{+}{\alpha}}$ & $\underset{\infty}{\stackrel{\sim}{\infty}}$ & $\stackrel{m}{\infty}$ & $\underset{\infty}{\stackrel{t}{\Delta}}$ & 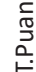 \\
\hline$\frac{2}{\frac{1}{4}}$ & 0 & 2 & 1 & 1 & 0 & 0 & 3 & 0 & 2 & 2 & 3 & 3 & 2 & 2 & 0 & 3 & 0 & 2 & 0 & 3 & 3 & 0 & 0 & 3 & 35 \\
\hline రా & 2 & 2 & 1 & 2 & 0 & 0 & 3 & 0 & 2 & 2 & 3 & 3 & 0 & 2 & 2 & 3 & 3 & 2 & 0 & 0 & 3 & 0 & 3 & 0 & 38 \\
\hline 訔 & 0 & 2 & 1 & 1 & 0 & 0 & 3 & 0 & 2 & 2 & 3 & 0 & 2 & 3 & 0 & 3 & 0 & 2 & 0 & 0 & 3 & 0 & 0 & 0 & 27 \\
\hline
\end{tabular}

Grup halinde olan öğrenciler daha önce, Taksi problemine benzer bir problemle karşılaşmadıklarını söylemiş ve aralarında şu şekilde bir diyalog geçmiştir:

Cenk: [...] Ama yok, karşılaştım. Önceki saksılı probleme benziyor sanki. Ama azıık benziyor.

Bora: Evet doğru biraz benziyor.

Alp: Neresi benziyor?

Bora: [...] Diğer saksılı soruda da şart veriyordu. Hani müşteri gelip alırsa bu kadar adrese isterse şu kadar. Hatırladın mı?

Alp: Evet benziyor biraz, fikrimi değiştim. íkisinde de para var. Paralı yeri benziyor. Benzemeyen yerler de var. Mesela ee bakayım bunda kilometre falan var. Onda km yoktu ki adam geliyor alıyor gidiyor o tarzdı.

Cenk verilen problemi Saksıdaki Çiçekler problemine benzettikten sonra, Bora da başlangıçtaki fikrini değiştirmiştir. Alp, iki problemin ne yönden benzediğini sorduktan sonra Bora şartlara göre değişen para miktarı olduğu yönünde bir benzerlik ilişkisi kurduğunu söylemiştir. Bunun üzerine Alp önceki düşüncesini değiştirmiş ve iki problem arasında benzerlik olduğunu kabul etmiştir. İlk başta olmasa da, üç öğrencinin deneyim temasının D1 göstergesi kapsamında yansıtma yapabildiği görülmüştür.

Problemin çözümüne geçilmeden önce, Cenk arkadaşlarına "Her bilgiyi kullanacak mıyız?" şeklinde bir soru sormuştur. Bora bu soruyu "Bence şu 19.30'a şimdilik gerek yok çünkü saat ile ilgili bir şey demedi. Boş bilgi." şeklinde, Alp ise "Bence de gerek yok çünkü kaçta ineceğini falan sormuyor ki." biçiminde cevaplamıştr.

Bora Cenk'in sorusuna karşııı, verilen 19.30 saatine gerek olmadığını, bu nedenle lüzumsuz olduğunu söyleyerek D2 bağlamında yansıtma yapmıştır. Alp de problemde Ahmet Bey'in kaçta ineceğini sormadığını, bu nedenle 19.30 bilgisine gerek duymadığını (D2) söyleyerek Bora'ya katıldığını belirtmiştir (G1).

İlerleyen süreçte, öğrenciler problemi çözerken aralarında şu şekilde bir diyalog geçmiştir:

Alp: [...] Yani 1 km'de 5 lira olur.

Bora: 5 km’de 25 lira olur o zaman. Şantiyeye kadar olan yol ücreti.

Cenk: 3,5 lira da baştan vardı, 28,5 şu ana kadar olan tutar.

Bora: Taksiyi $15 \mathrm{dk}$ bekletmiş. 0,30’la 15'i çarpacağız 4,5 lira yapar (B4-). Yani şu ana kadar ödemesi gereken para 28,5 ile 4,5'un toplamından 33 lira yapar.

Alp: 39 TL veriyor o zaman kalıyor 6 lira.

$[\ldots]$

Alp: Buldum. 1200 metre daha gitti. Çünkü her 200 metrede 1 liraydı. O zaman 6 ile 200'ü çarparsak 1200 olmaz mı?

Bora: 1 lirada 200 metre giderse 6 lirada kaç doğru orant oluyor yani, haklısın (G1).

Öğrenciler grup içinde gerçekleşen fikir alışverişleri yardımıyla, problemin sonucuna ulaşabilmiştir (Şekil 6). Üç öğrenci de problem çözümüne katkıda bulunmuştur. Fakat öğrenciler çözümlerinde yaptkkları işlemlerin nedenleri hakkın- 
da konuşmamışlar, dolayısıyla B3 göstergesi kapsamında eksik yansıtma yapmışlardır. Ayrıca Bora, doğru orant kullanarak sonucun 1200 metre çıkacağını söyleyerek Alp'e katıldığını belirterek G1 göstergesi kapsamında yansıtma yapmıştır.

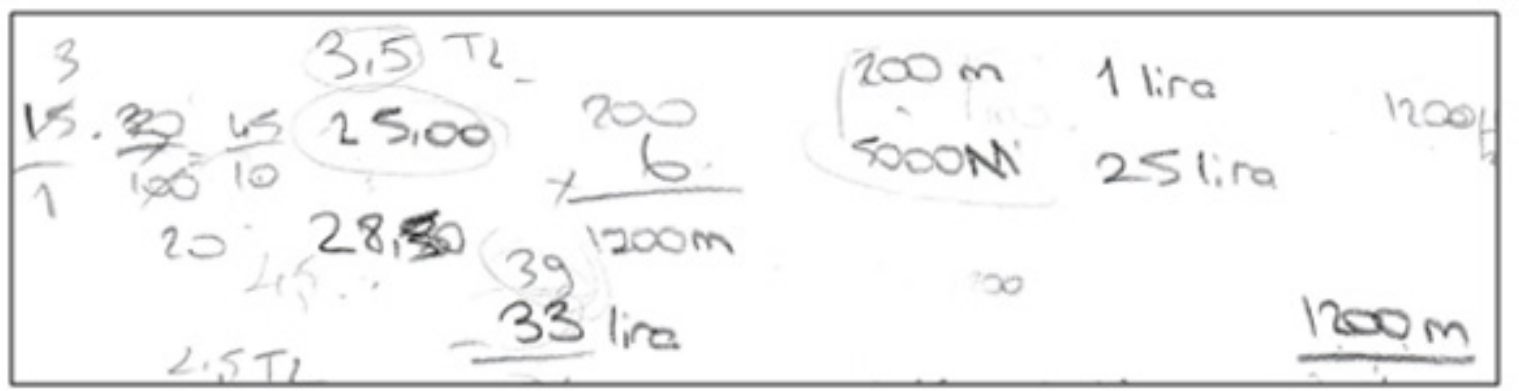

\section{Şekil 6. Öğrencilerin "Taksi Problemi” için Yaptıkları Çözüm}

İlerleyen süreçte, Bora problemi ikinci bir yoldan çözebileceklerini belirterek "Farklı yol denklem olabilir. Şantiye ile restoran arasındaki uzaklık bilinmiyor. Bilinmeyen var yani." demiştir. Öğrenciler arasında gerçekleşen fikir alışverişleri üzerine diyalog, bir sonraki aşamada neyi ve neden yapacağını ifade etmeksizin (B4-), şöyle devam etmiştir:

Bora: $O$ zaman şöyle kuralım denklemi. 3,5 zaten vardı. 5 km'yi ifade etmek için de 5000 metre yapar. İlk başlarda yaptığımı gibi 5000/50 yapsak bunu 0,25 ile çarparsak olur yani şöyle olacak: 3,5+ (5000/50).0,25

Cenk: $15.0,30$ ekle.

Bora: Tamam şöyle olacak. 3,5+(5000/50).0,25+(15.0,30) şimdi x'li yeri ekleyeceğiz, x restoran ile şantiye arası olsun. Nasıl ekleyeceğiz?

Cenk: 50 metre 0,25 ise 1 metreyi bulalım x ile çarparız, orant kuralım bence.

[...]

Bora: $O$ zaman 3,5+(5000/50).0,25+(15.0,30)+(x.0,25/50)=39 oldu mu?

Cenk: Oldu çözelim. 5000/50= 100 eder. 100'ü 0,25 ile çarparsak 25.

Alp: $15 \cdot 0,30$ eder 4,5. Düzenleyelim 3,5+25+4,5+x.0,25/50=39 yani $33+x \cdot 0,25 / 50=39$. Buradan $x \cdot 0,25 / 50=6$ olur. Devamında da...

Bora: İçler dışlar çarpımı yap x.0,25=300, bu da $x / 4=300$ yapar.

Cenk: Yani $x=1200$ çıkt. Doğru yapttk (B7-).

Öğrenciler problemi denklem yardımıyla ikinci bir yoldan çözebilmiştir. Bu çözüm sürecinde bireysel olarak B9 göstergesi kapsamında eksik yansıtmalar yapmış olsalar da grup olarak oldukça başarılı yansıtmalar yapabilmişlerdir.

Alp, Bora ve Cenk ilk seçtikleri çözüm yolunun kendilerine göre daha iyi olduğunu belirtmişlerdir. Öğrenciler bunun nedenini denklem kurmanın düşündürücü ve zor olmasına bağlamışlardır (D6). Bu açıklamalara Alp, denklem oluşturmada zorlandığını buna rağmen denklem çözmede iyi olduğunu eklemiştir. Cenk ise bu problemin çözümüne yönelik denklem oluşturma sürecinin Saksıdaki Çiçekler problemindeki denklemi oluşturmaya göre daha zor olduğunu söylemiştir.

Alp problemi ilk kez okuduğunda, içinde problemin zor çözülebileceğine dair bir his uyandığını söylemiş ve bunun nedenini problemin uzun olmasına bağlamıştı (H1). Bora ve Cenk ise Taksi problemini ilk okuduklarında problemin kendilerine kolay geldiğini, bu nedenle problemi çözebilecekmiş gibi hissettiklerini belirtmişlerdir (H1). Öğrenciler problemi çözüp sonuca ulaşabildiklerinden dolayı mutlu olduklarını söylemişlerdir (H3). Buna ilaveten, Bora "Sonucu bulduğumuzda üçümüzün de matematikte iyi olduğunu anladım." derken, Cenk ise "Sonucu bulduğumuzda ise iyi bir matematik öğrencisi olduğumu gördüğüm için kendimi çok iyi hissettim. Çünkü verilen problemi başarı ile sonuçlandırmada katkım oldu." (H3) şeklinde bir açıklama yapmıştır. Bora ve Cenk problemin sonucunu bulabildikleri için kendilerini başarılı birer öğrenci olarak değerlendirdikleri görülmektedir.

İki problemden elde edilen bulgular doğrultusunda, Saksıdaki Çiçekler problemine kıyasla, Taksi probleminin çözüm sürecinde en kapsamlı yansıtmayı Bora'nın sergilediği görülmüştür. Cenk ise Taksi probleminde diğer iki öğrenciye kıyasla daha pasif kalmış ve daha az yansıtma ortaya koymuştur.

| Kastamonu Eğitim Dergisi, 27(2), 2019| 
Öğrenciler kendileriyle yapılan görüşmeler sırasında grup olarak problem çözmenin destekleme, süreci hızlı değerlendirme, sonuçtan daha emin olma gibi kolaylıklar sağladığını belirtmekle birlikte; tartışmak zorunda kalınması, ortak noktayı bulmanın uğraştırıcı olması, tartışmanın süreyi uzatması gibi zor yönleri olduğunu ekleyerek şunları söylemişlerdir:

Alp: [...] Grupla olunca problemin değerlendirme aşaması daha hızlı oluyor.

Bora: Grupla çözdüğümde bulunan sonuçtan daha emin oluyorum. [...]

Cenk: Kolay olan yönleri şöyle, birisinin açığını başkası kapatıyor, tamamlıyor yani. Mesela ben yanlış bir şey deyince diğeri düzeltebiliyor. Ama zor yönü de tartışmaya düşmek. Bu durum uzayınca sıkılıyorum.

Görüşmeler sırasında öğrenciler bireysel olarak problem çözmenin birini dinlemek zorunda olmama, kısa sürede sonuca ulaşma gibi kolaylıklar sağladığını belirtmekle birlikte; bazen problemi uzun sürede anlama, hata yapınca hemen fark edememe, sonuçtan emin olamama gibi zor yönleri olduğunu belirterek şu şekilde açıklama yapmışlardır:

Bora: Kolay şu, karşımda biri yok. Kendi bildiğim gibi yapıyorum. Zor olan yönü de şu, işlem hatası yaptığımı anında fark edemeyebiliyorum. Bazen de problemi uzun sürede, tekrar tekrar okuyarak anlıyorum.

Alp: Kolayı, başkası ile tartş̧mak durumunda kalmıyorum. Kendim çözünce daha mutlu oluyorum. Zor yönü bence yok.

Cenk: Kolay yönü, daha kısa sürede çözüyorum. Bireysel olunca kendimi daha iyi ortaya koyuyorum. Zor yönü ise, bazen bulduğum sonuçtan emin olamıyorum. Yaptığım işlemi anında düzelten yok çünkü. İşlem hatası yaptım mı diye düşünüyorum.

\section{Tartışma}

Matematik problemlerini çözmede başarılı öğrencilerin yansıtıcı düşünme becerilerinin incelendiği bu araştırmada, öğrencilerin genel olarak bilgi, deneyim ve bağlam temaları çerçevesinde başarılı şekilde olmakla birlikte, his/duygu ve grup arkadaşı temalarında da yansıtmalar ortaya koyabildikleri, buna rağmen belirlenen göstergeler dâhilinde yansıtma yapmakta zorlandıkları, eksik yansıtma yapabildikleri veya herhangi bir yansıtma yapamadıkları durumların da olduğu sonucuna ulaşılmıştir.

Öğrenciler problemleri özetlerken kendi cümlelerini kurmak yerine, problemi tekrar okuyarak problemde yer alan bilgileri benzer şekilde söyleme yoluna gitmişlerdir. Bu sonuca paralel olarak, Aydemir ve Kubanç (2014) yaptıkları çaıışmada bazı öğrencilerin problemi kendi cümleleri ile açıklamak yerine tekrar okumayı tercih ettiklerini belirlemiştir. Bu durum, öğrencilerin problemde verilen ve istenenleri aynı şekilde ifade etmenin problemi özetlemek olduğunu düşündükleri göstermektedir. Öğretmenlerin derslerinde sadece problem çözmeye değil, öğrencilerin bu problemleri anlamaları, özetlemeleri ve yorumlamaları üzerine yoğunlaşmaları bu eksikliği ortadan kaldırmaya yardımcı olabilir.

Araştırma sonucunda öğrencilerin BPÇE'lerinde, daha önce karşılaştıkları benzer problemde kullandıkları stratejiyi kullanma eğilimi gösterdikleri ve bu doğrultuda yansıtmalar ortaya koydukları görülmüştür. Polya (1957) başarılı problem çözücülerin önceden çözdükleri problemleri hatırladıklarını ve benzer stratejileri kullanarak problemleri çözmeye çalıştıklarını ve bunun önemli olduğunu belirtmiştir. Öğrencilerin uygulama boyunca kimi zaman araştırma öncesindeki, kimi zaman da araştırma sürecindeki problem çözüme etkinliklerinde edindikleri deneyimleri üzerine başarılı yansıtmalar yaptıkları görülmüştür. Öğrenciler bu sayede başarılı bir problem çözüm süreci sergilemişlerdir. Ahmed, Wallace ve Blessing (2003) çalışmalarında başarılı problem çözücülerin problemle karşılaştıklarında olası çözümler üretmek amacıyla deneyimleri üzerine yansıtmalar yaptkklarını belirtmiştir. Araştırma sonucunda ulaşılan bulgular bu çalışmaların sonuçlarıyla paralellik göstermektedir. Problem çözme sürecinde deneyimin önemli bir faktör olduğuna işaret etmekte olan bu husus, öğrencilerin benzer problemlerle daha önce karşılaşmış olmaları sayesinde sahip oldukları deneyimlerinin problem çözme sürecini olumlu yönde etkilediği şeklinde yorumlanabilir.

Öğrencilerin problemlere çözüm üretmelerinde hem deneyimlerinin hem de matematiksel bilgilerinin yansıtmalar üzerinde etkili olduğu görülmüştür. Öğrenciler bu sayede deneyimlerini ve bilgilerini yeni durumlara uyarlayabilmişlerdir. Öğrencilerin mevcut bilgileri, yansıtma sürecini kolaylaştıran önemli bir faktördür (Renkl, 2002) ve yansıtmalar sayesinde bilgi yeni durumlara kolaylıkla transfer edilebilmektedir (Ertmer ve Newby, 1996). Öğrencilerin hem bilgilerinin hem de deneyimlerinin problem çözme sürecinin önemli bir bileşeni olduğu göz ardı edilmemeli ve problem çözme sürecinde bunlar etkili bir şekilde kullanılabilmelidir.

Öğrenciler uygulama sürecindeki problemler için ikinci bir çözüm yolu sunarken başarılı yansıtmalar ortaya koymuşlardır. Ng ve Tan (2006) çalışmalarında öğretmen adaylarının ikinci bir çözüm yolu için yeterince yansıtma yapa- 
madıklarını belirtmiştir. Baki, Güç ve Ozmen (2012) yaptikları çalışmalarında öğretmen adaylarının verilen problem için ikinci bir çözüm yolu ortaya koymadığını ve öğretmen adaylarının bunu gereksiz gördüklerini tespit etmiştir. Araştırma sonucunda ulaşılan bulgular bu çalışmaların sonuçlarıyla tutarlılık göstermemektedir. Bunun muhtemel sebeplerinden birisi araştırmacının derslerinde problemleri farklı çözüm yolları kullanarak çözmeye odaklanması olabilir.

Öğrenciler seçtikleri farklı çözüm yollarından kendilerine göre daha iyi olanı nedenleriyle birlikte ifade edebilme konusunda genel olarak başarılı şekilde yansıtma yapabilmişlerdir. Bu sonuç Bingham (2004) ve Shermis'in (1992) görüşleri ile paralellik göstermektedir.

Alp Saksıdaki Çiçekler Problemi için farklı bir çözüm yolu olarak denklem kurabilmiştir. Fakat denklem çözümünde 33/1,65 ifadesi ile yeniden karşılaşmış fakat sonucu aynen almak yerine bir süre düşünmüş ve 1,65'i kesir olarak yazıp bölme işlemi yapabilmiştir. Alp'in matematiksel bilgileri arasında ilişkilendirme yapıp yeni bir fikir üretebildiği görülmüştür. Benzer şekilde Yorulmaz (2006) çalışmasında yansıtıcı düşünebilen öğrencilerin süreç içerisinde düşünerek yeni fikirler ürettiğini böylece problemleri çözebildiklerini belirtmiştir. Yeşilova (2013) da çalışmasında öğrencilerin bazı problemlerde matematiksel kuralları unuttuklarını ancak bu durumlarda endişelenmeyip pes etmeyerek alternatif yollar denediklerini, çözüm yöntemi üretmeye çalıştıklarını tespit etmiştir. Bu sonuçlardan hareketle, öğrencilerin problem çözme süreçlerinde bilgileri veya deneyimleri üzerine yansıtıcı düşünmeler gerçekleştirmelerinin yanı sıra sebat göstermelerinin de problem çözme performansı için önemli bir etken olduğu söylenebilir.

Öğrenciler süreç içerisindeki yansıtmaları sayesinde verilen problemlere benzer bir problem kurabilmiştir. Öğrenciler genellikle verilen problemdeki koşulları ve konuyu değiştirmeyip, sayısal değerleri değiştirerek benzer bir problem oluşturmuşlardır. Benzer şekilde Tertemiz ve Sulak (2013) da çalışmalarında öğrencilerin çoğunun verilen problem durumundaki koşulları ve konuyu değiştirmeyip, sadece verileri değiştirerek yeni problem kurdukları sonucuna ulaşmışlardır. Bu durumun olası sebeplerinden biri öğrencilerin problem kurma bağlamında çözme kadar deneyim sahibi olmamaları olabilir. Öğrenciler aynı zamanda, oluşturdukları benzer problemlerin çözülebilir olduğunu kontrol ederek göstermişlerdir. Kişinin matematiksel bilgisi ile problem kurma performansı incelendiğinde, daha yüksek matematik bilgiye sahip öğrencilerin daha uygun ve çözülebilir problemler üretebildiği görülmektedir (Leung, 1993).

Yapılan bu çalışma sonucunda bireysel ve grup olarak problem çözüm sürecine etkin kathlım bakımından en belirgin farkın Cenk'te olduğu görülmüştür. Cenk bireysel problem çözüm sürecinde başarılı yansıtmalar yardımıyla bu süreci iyi bir performansla sonlandıırken, grup olarak problem çözüm sürecinde pasif kalmıştı. Cenk grupla çalışma sürecinde meydana gelen tartışmaların çözüm sürecini uzattı̆ııı, bu nedenle sıkıldığını belirterek başkalarıyla birlikte problem çözmeyi sevmediğini söylemiştir. Alp ve Bora da Cenk ile benzer görüş ortaya koymuşlardır. Bu da göstermektedir ki bu öğrenciler problemi birlikte çözmektense, bireysel olarak çözmeyi tercih etmektedirler. Ayrıca öğrencilerin bireysel çözüm sürecinde başarılı yansıtmalar yapabilmelerine rağmen grup çalışmalarında yansıtmalarının daha düşük seviyede olduğu görülmüştür. Fakat alan yazında akran işbirliği üzerine yapılan çoğu çalışma, öğrencilerin bir amacı gerçekleştirmek için bireysele kıyasla daha yüksek performans sergilediğini göstermiştir (Moshman ve Geil, 1998, Fawcett ve Garton, 2005). Bu farklıığın muhtemel sebeplerinden birisi bu çalışmanın problem çözme becerisi yüksek olan öğrencilere odaklanması ve bu öğrencilerin okullarında çoğunlukla bireysel çalışmalar yapıyor olmaları olabilir.

Öğrencilerin grup sürecindeki yansıtmalarının genel olarak anlaşılmayan veya yanlış anlaşılan yerleri açığa kavuşturmaya, ortaya atılan fikirleri değerlendirip elemeye, birbirlerine uygun geri bildirimler vermeye yönelik olduğu görülmüştür. Benzer şekilde Fawcett ve Garton (2005) çalışmalarında iki kişi çalışan öğrencilerin birbirlerinin söylediklerini değerlendirdiğini, anlaşılmayan yerleri birbirlerine açıkladıklarını tespit etmiş; Sarıtaş (2002) da çalışmasında başarıı problem çözücülerin işbirliği halindeyken anlamadıkları yer olduğunda birbirine açıklama yaptıklarını belirlemiştir. Grup olarak çalışma, ayrıca problemin kontrol ve değerlendirme aşamasını da kolaylaştırmakta, gruptakilerin birbirlerinin düşünceleri üzerinde sorgulamalar yaparak çoğu zaman doğru çözüme ulaşabilmelerine yardımcı olmaktadır (Yann-Shya, 2010). Bu görüşle uyumlu olarak bu çalışmada da öğrencilerin, grup çalışmasının farklı çözüm stratejileri ortaya koyabilme, bulunan sonuçtan daha emin olabilme, çözümü kolay değerlendirebilme gibi olumlu yanları olduğunu düşündükleri görülmüştür. Bu sonuçlar öğrencilerin grup halinde problem çözerken sürecin her aşamasında birbirlerinin görüşlerinden istifade edebildiklerine ve bu sayede daha etkili çözümler geliştirebildiklerine işaret etmektedir.

Yukarıda da belirtildiği gibi öğrencilerin bireysel ve grup olarak problem çözme sürecindeki yansıtmalarını ortaya çıkarmak, onların problem çözme sürecindeki başarılı ve başarısız oldukları hususları tespit edebilmek öğretmenlerin daha iyi bir öğretim ortamı hazırlayabilmeleri için önemlidir. Bu araştırma özel olarak problem çözmede başarılı öğrencilerin yansıtıcı düşünme becerilerini ortaya çıkarmaya odaklanmıştı. Bununla beraber farklı sınıf seviyelerinde ve problem çözme becerisi değişik seviyelerde olan öğrenciler üzerine yapılan benzer çalışmaların sayısı azdır. Bundan sonraki araştırmalarda bu hususlara odaklanmak, öğrencilerin her seviyede ne tür yansıtıcı düşünme becerilerine sahip olduklarını ortaya çıkarması bakımından önemlidir. Ayrıca yansııcı düşünme becerilerini geliştirmek için nasıl bir öğre-

| Kastamonu Eğitim Dergisi, 27(2), 2019| 
tim ortamı tasarlanması gerektiğine yönelik çalışmalar yapılması da bu çalışmada elde edilen sonuçların farklı boyutlardan tartışılmasına olanak sağlayacaktır.

\section{Kaynakça}

Adams, R. S., Turns, J. ve Atman, C. J. (2003). Educating Effective Engineering Designers: The Role of Reflective Practice. Design Studies, 24(3), 275-294.

Ahmed, S., Wallace, K. M. ve Blessing, L. M. (2003). Understanding the Differences Between How Novice and Experienced Designers Approach Design Tasks. Research in Engineering Design, 14(1), 1-11.

Aydemir, H. ve Kubanç, Y. (2014). Problem Çözme Sürecinde Üst Bilişsel Davranışların İncelenmesi. Turkish Studies, 9(2), $203-219$.

Baki, A., Güç, A. F. ve Özmen, Z. M. (2012). Illköğretim Matematik Öğretmeni Adaylarının Problem Çözmeye Yönelik Yansıtıcı Düşünme Becerilerinin Incelenmesi. Uluslararası Eğitim Programları ve Öğretim Çalışmaları Dergisi, 2(3), 60-72.

Baş, G. ve Kıvılcım, Z. S. (2011). Lise Öğrencilerinin Problem Çözmeye Yönelik Yansıtıcı Düşünme Becerileri ile Matematik ve Geometri Derslerindeki Akademik Başarıları Arasındaki İlişki. Kırşehir Eğitim Fakültesi Dergisi, 14(3), 1-17.

Bjuland, R. (2004). Student Teachers' Reflections on Their Learning Process Through Collaborative Problem Solving in Geometry. Educational Studes in Mathematics, 55, 199-225.

Can, S. (2015). Pre-service Science Teachers' Reflective Thinking Skills Toward Problem Solving. Educational Research and Reviews, 10(10), 1449-1457.

Çepni, S. (2009). Araştırma ve proje çalışmalarına giriş (Geliştirilmiş 4.baskı). Ankara: Pegem Yayınları.

Demirel, M., Derman, I. ve Karagedik, E. (2015). A Study on the Relationship Between Reflective Thinking Skills Towards Problem Solving and Attitudes Towards Mathematics. Procedia - Socialand Behavioral Sciences, 197, 2086 - 2096.

Dewey, J. (1933). How we think. A restatement of the relation of reflective thinking to the educative process. Boston: D. C. Heath. Ertmer, P. A. ve Newby, T. J. (1996). The Expert Learner: Strategic, Self-Regulated and Reflective. Instructional Science, $24,1-24$.

Fawcett, L. M. ve Garton, A. F. (2005). The Effect of Peer Collaboration on Children's Problem-Solving Ability. British Journal of Educational Psychology, 75, 157-169.

Ferri, R. B. (2003). Mathematical thinking styles - an empirical study. Erişim Tarihi: 19 Ekim 2015, http://www.dm.unipi.it/ $\sim$ didattica/CERME3/proceedings/Groups/TG3/TG3_BorromeoFerri_cerme3.pdf.

Güneş, K. (2015). Bilim sanat merkezi öğrencilerinin problem çözmeye yönelik yansıtıcı düşünme becerileri, matematik dersine yönelik tutumları ve matematik başarılarının incelenmesi (Yayımlanmamış Yüksek Lisans Tezi). Çukurova Üniversitesi, Adana.

Hong, Y. C. (2011). Exploring novice designers' reflective thinking in solving design problems (Unpublished doctoral dissertation). Georgia University, Athens.

Hong, Y.C. ve Choi, I. (2011). Three Dimensions of Reflective Thinking in Solving Design Problems: A Conceptual Model. Education Technology Research and Development, 59, 687-710.

Hong, Y.C. ve Choi, I. (2015). Assessing Reflective Thinking in Solving Design Problems: The Development of a Questionnaire. British Journal of Educational Technology, 46(4), 848-863.

Kember, D., Leung, D., Jones, A., Loke, A. Y., McKAy, J. Sinclair, K. Tse, H., Webb, C., Wong, F. K. Y., Wong, M. ve Yeung, E. (2000). Development of a Questionnaire to Measure the Level of Reflective Thinking. Assessment \& Evaluation in Higher Education, 25, 380-395.

Kızılkaya, G. ve Aşkar, P. (2009). Problem Çözmeye Yönelik Yansıtıcı Düşünme Becerisi Ölçeğinin Geliştirilmesi. Eğitim ve Bilim Dergisi, 34(154), 83-92.

Leung, S. S. (1993). The relation of mathematical knowledge and creative thinking to the mathematical problem posing of prospective elementary school teachers on tasks differing in numerical information content (Unpublished Doctoral Dissertation). Pittsburg University, Pittsburg.

Mahnaz, M. (1997). Content and Nature of Reflective Teaching: A Case of an Experiment Middle School Science Teacher. Clearing House, 70(3), 143-151.

Milli Eğitim Bakanlığı [MEB] (2018). Matematik dersi öğretim programı. T.C. Milli Eğitim Bakanlığı, Ankara.

Mezirow, J. (1991). Transformative dimensions of adult learning. San Francisco: Jossey-Bass.

Moshman, D. ve Geil, M. (1998). Collaborative Reasoning: Evidence for Collective Reality. Thinking and Reasoning, 4, $231-248$.

Ng, C.S.L. ve Tan, C. (2006). Investigating Singapore Pre-service Teachers' III-Structured Problem Solving Processes in an Asynchronous Online Environment: Implications for Reflective Thinking. New Horizons in Education, 54, 1-15.

Öztürk, S. (2003). Developing a reflective reading model (Yayımlanmamış Yüksek Lisans Tezi). Marmara Üniversitesi, İstanbul.

Polya, G. (1997). Nasıl çözmeli? (F. Halatçı, Çev.). İstanbul: Sistem Yayıncılık.

Renkl, A. (2002). Learning from Worked-out Examples: Instructional Explanations Supplement Self Explanations. Learning and Instruction, 12, 149-176. 
Sarıtaş, E. (2002). Işbirlikli ve geleneksel sınıflardaki başarılı ve başarısız problem çözücülerin kullandıkları öğrenme stratejileri, tutumları ve edim düzeyleri (Yayımlanmamış Doktora Tezi). Dokuz Eylül Üniversitesi, İzmir.

Saygılı, G. ve Atahan, R. (2014). Üstün Zekâlı Çocukların Problem Çözmeye Yönelik Yansıtıcı Düşünme Becerilerinin Çeşitli Değiş̧kenler Bakımından Incelenmesi. SDÜ Fen Edebiyat Fakültesi Sosyal Bilimler Dergisi, 31, 181-192.

Shermis, S. S. (1992). Critical Thinking: Helping Students Learn Reflectively. Bloomington: EDINFO Press.

Şen, Ş. (2013). Reflective Thinking Skills of Primary School Students Based on Problem Solving Ability. International Journal of Academic Research, 5(5), 41-48.

Tat, O. (2015). Ortaokul öğrencilerinin problem çözmeye yönelik yansıtıcı düşünme becerilerini etkileyen faktörlerin hiyerarşik doğrusal modeller ile incelenmesi (Yayımlanmamış Yüksek Lisans Tezi). Yüzüncü Yıl Üniversitesi, Van.

Tertemiz, N. ve Sulak, S. E. (2013). İlköğretim Beşinci Sınıf Öğrencilerinin Problem Kurma Becerilerinin İncelenmesi. ilköğretim Online, 12 (3), 713-729.

Tripp, D. (2003). Action inquiry. 15 Eylül 2015, http://www.scielo.br/pdf/epp/_k31n3/en_a09v31n3.pdf.

Tuncer, M. ve Özeren, E. (2012). Prospective Teachers' Evaluations in Terms of Using Reflective Thinking Skills to Solve Problems. Procedia - Socialand Behavioral Sciences, 51, $666-671$.

Visscher-Voerman, I. ve Gustafson, K. L. (2004). Paradigms in the Theory and Practice of Education and Training Design. Educational Technology Research and Development, 52(2), 69-89.

Yann-Shya, W. (2010). The Effects of Collaborative Problem Solving on Individual Problem-Solving Ability. National Convention of the Association for Educational Communications and Technology, 1(2), 482-489.

Yeşilova, Ö. (2013). İlköğretim 7. sınıf öğrencilerinin problem çözme sürecindeki davranışları ve problem çözme başarı düzeyleri (Yayımlanmamış Yüksek Lisans Tezi). Marmara Üniversitesi, İstanbul.

Yıldırım, A. ve Şimşek, H. (2013). Sosyal bilimlerde nitel araştırma yöntemleri (Geliştirilmiş 9.baskı). Ankara: Seçkin Yayınları.

Yorulmaz, M. (2006). Ilköğretim I. kademesinde görev yapan sınıf öğretmenlerinin yansıtıcı düşünmeye ilişkin görüş ve uygulamalarının değerlendirilmesi (Diyarbakır ili örneği) (Yayımlanmamış Yüksek Lisans Tez). Fırat Üniversitesi, Elazığ. 